\title{
PSYCHIATRIC DISORDERS IN PATIENTS WITH NEUROFIBROMATOSIS
}

\author{
Marija Bogadi ${ }^{1}$, Snježana Kaštelan², Ivana Bakija ${ }^{3}$, Boris Kasun ${ }^{4}$ \\ ${ }^{1}$ Psychiatric Hospital for children and adolescents, Zagreb, Croatia; \\ ${ }^{2}$ Department of Ophthalmology, University Hospital Dubrava, \\ School of Medicine University of Zagreb Zagreb, Croatia; \\ ${ }^{3}$ Psychiatric Hospital "Sv. Ivan", Zagreb, Croatia; \\ ${ }^{4}$ Special Hospital for Medical Rehabilitation Stubičke Toplice, Stubičke Toplice, Croatia
}

\begin{abstract}
Summary
The "neurofibromatoses" (NFs) are a group of distinct genetic disorders that are commonly associated with the appearance of nerve tumours. They include NF1, NF2 and schwannomatosis, with the NF1 or von Recklinghausen disease being the most common form. All these disorders are dominantly inherited with a high rate of new mutation and variable expression. It is typically regarded as a cancer predisposition syndrome; however the most common complication of NF1 in childhood is impairment in academic achievement and cognition with attentional, executive, language and visuospatial functions frequently affected. This paper therefore, attempts to emphasize the existence and importance of psychological disorders and difficulties in people with NF1. Early detection of existing psychiatric disorders in NF1 patients opens the possibility of early treatment and better quality of life. In this study an overview of the latest findings regarding mental disorders in NF1 patients is given. The majority of studies to date have based their investigation on cognitive impairments whose frequency is high in NF1 patients. Other investigations describe the problems of socialization, quality of life and the possibility of medical treatment. It is important that specialists of different areas of expertise have a clear overview of all mental disorders and difficulties that may occur in people affected by this disease. The importance of a multidisciplinary approach to treatment is also emphasized, which will lead to more successful forms of treatment and improve the quality of life of patients with NF1.
\end{abstract}

KEY WORDS: neurofibromatosis, mental disorders, cognitive difficulties, ADHD, autism

\section{PSIHIJATRIJSKI POREMEĆAJI U BOLESNIKA S NEUROFIBROMATOZOM}

\section{Sažetak}

Neurofibromatoze (NF) su skup različitih genetskih poremećaja kojima je zajednička karakteristika pojava tumora živčanog sustava. Razlikuju se tri oblika bolesti: NF1, NF2 i švanomatoza, a najčešći oblik je NF1 ili von Recklinghausenova bolest. Neurofibromatoze se nasljeđuju autosomno dominantno s visokom stopom novih mutacija i varijabilnom ekspresijom. Iako se NF1 smatra bolešću s povećanim rizikom za razvoj tumora, njena najčešća komplikacija u djetinjstvu je oštećenje akademskog postignuća i spoznaje, pri čemu su često pogođene pozornost, izvršne, jezične i vizualno-prostorne funkcije. Stoga se ovim radom željelo ukazati na važnost psihičkih poremećaja i poteškoća kod osoba oboljelih od NF1. Njihovo rano uočavanje otvara mogućnost ranijeg početka liječenja, a time bolje kvalitete života bolesnika. U radu je dan pregled novih spoznaja o psihičkim poremećajima koji se mogu javiti kod oboljelih od NF. Prikazana su istraživanja koja su pokušala objasniti pojedine psihičke funkcije kod oboljelih osoba. Najveći broj istraživanja bavi se kognitivnim poteškoćama čija je učestalost kod oboljelih od NF1 vrlo visoka. Ostala istraživanja opisuju probleme socijalizacije i kvalitete života te moguć- 
nosti medikamentoznog liječenja psihičkih poremećaja. Važno je i korisno da stručnjaci različitih specijalnosti imaju šire znanje o psihičkim poremećajima i poteškoćama koje se mogu javiti kod osoba oboljelih od NF1. Također se ovim radom željela naglasiti važnost multidisciplinarnog pristupa kod liječenja NF čime će se postići i uspješnije liječenje i poboljšati kvaliteta života bolesnika.

KLJUČNE RIJEČI: neurofibromatoza, psihički poremećaji, kognitione poteškoće, ADHD, autizam

\section{INTRODUCTION}

The "neurofibromatoses" (NFs) are a group of distinct genetic disorders that are commonly associated with the appearance of nerve tumours. They include NF1, NF2 and schwannomatosis, with the NF1 or von Recklinghausen disease being the most common form. All these disorders are dominantly inherited with a high rate of new mutation and variable expression. NF1 has an effect on multiple systems of the body. The main NF1-associated tumour is the neurofibroma. NF2 includes schwannomas of multiple cranial and spinal nerves, particularly the vestibular nerve, as well as other tumours such as meningiomas and ependymomas. The schwannomatosis phenotype is limited to multiple schwannomas and usually accompanied with pain. The genes that underlie each of the disorders that are known include NF1 for neurofibromatosis type 1 which resides on chromosome 17q11.2, NF2 for neurofibromatosis type 2, and INI1/SMARCB1 for schwannomatosis (1). Diagnostic features of NF1 include alterations in skin pigmentation (café au lait spots, skinfold freckling), Lisch nodules and the above mentioned nervous system tumours (neurofibromas and optic pathway gliomas). Additionally, clinical manifestations include bone dysplasia, learning disabilities and an increased risk of malignancy (2). Birth incidence of NF1 is 1 in 2700. It is typically regarded as a cancer predisposition syndrome, however the most common complication of NF1 in childhood is impairment in academic achievement and cognition, with attentional, executive, language and visuospatial functions frequently affected (3-6). However, in patients with NF very little is known about these type of disorders. The intention of this paper is to emphasize the existence and importance of psychological disorders and difficulties in people with NF1. It is important that specialists of different areas of expertise have a clear overview of all mental disorders and difficulties in people affected by this disease. The im- portance of a multidisciplinary approach to treatment is also emphasized, which will further lead to more successful forms of treatment and improve the quality of life of patients with NF1.

\section{Attention deficit hyperactivity disorder and neurofibromatosis type 1}

Hyperactivity or hyperkinesis disorder (attention deficit hyperactivity disorder - ADHD) is defined as a trias involving hyperkinesia, attention deficit and impulsivity (7). The incidence of ADHD in patients with NF1 ranges between 33\% and $49.5 \%$ and is equally common in both sexes (8). According to the Centre for Disease Control and Prevention (CDCP) report from 2011-2013, the percentage of ADHD diagnosed among children between the ages of 4 to 17 was $11.5 \%$, and by sex: $13.3 \%$ in males and $5.6 \%$ in females (2). The ADHD-like symptoms in NF1 appear to involve complex impairments in cognitive processes, visuospatial function and executive function that may operate through mechanisms that probably differ from those responsible for ADHD in individuals without NF1 $(3,9)$. Researchers have suggested that impaired reactivity to visual signals may play a role (4). In the research conducted by Sanchez-Marco et al (9), 56 patients with NF1 were included. Twenty three patients $(41 \%)$ were diagnosed with ADHD with the mean age at ADHD diagnosis being $7.53 \pm 2.46$ years. School-age children with ADHD represented $48.8 \%$ of cases. All but one of the children received treatment and the mean duration of treatment was $3.85 \pm 3.04$ years. Positive effects were reported by eleven patients with a moderate response in eight patients. The research results confirm the high prevalence of ADHD in patients with NF1. Early diagnosis and treatment of ADHD in patients with NF1 is highlighted and the results reveal good patient adherence and medical treatment outcomes in most patients if the diagnosis and treatment are timely initiated (9). Several studies suggest that the cognitive, motor, learning, and social problems often 
identified in patients with NF1 are not a distinct comorbidity of the disease but rather a direct consequence of NF1 pathology (10). Koth et al (11) compared the ADHD status of children with NF1 to that of their healthy siblings and biological parents and found a significant connection between NF1 and ADHD, suggesting that ADHD occurs as a component of the underlying disease.

Cohen et al (12) investigated whether the use of MOXO visual- and vocal-distractors-based continuous performance test enabled the distinction of patients with ADHD and NF1 from those without NF1. The results showed that MOXO scores was significantly worse in patients with NF1 than in controls, however the test cannot differentiate between NF1 with ADHD characteristics and ADHD without NF1. The test highlights sex differences in ADHD characteristics in NF1 with impulsivity and hyperactivity being more prominent in males than females. Over reactivity to visual distractors may form part of the attention deficit in NF1. Similar research with the same aim and yielding similar result was carried out by LionFrançois et al (13). They compared children with NF1 and associated ADHD symptomatology (NF1 + ADHD) with children diagnosed with ADHD without NF1. The hypothesis was that performance differences in tasks of attention between these two groups would be attributable not to ADHD symptomatology, but to NF1 alone. Children of both groups and the group of healthy controls participated in a set of computerized tasks assessing intensive, selective and executive aspects of attention. Children with NF1 + ADHD did not always perform worse than children with ADHD. It was concluded that ADHD symptomatology in NF1 does not contribute to all attention deficit, and ADHD cannot account for all attention impairments in NF1.

\section{Autistic disorder and neurofibromatosis type 1}

The association between NFs and autistic disorders is an area of great interest for researches. Autism is characterised by changes in behaviour in all areas of the central nervous system (CNS): motoric, perceptual, intellectual, emotional and social. According to the Diagnostic and Statistical Manual of Mental Disorder-IV (DSM-IV) classification and International Classification of Diseas- es-10 Edition the essential feature of autistic disorder is the abnormal or impaired development of social interactions and communication, a markedly reduced repertoire of activity and interest as well as manifestations of disorder differing according to developmental stage and chronological age (14). Eijk et al (15) found that the prevalence rate of autism spectrum disorder (ASD) in children with NF1 was $10.9 \%$, which is higher than in the general population estimated at $3-6$ per 10,000 (14). Further they concluded that the combined observational and screening based classifications demonstrated the highest positive predictive value for DSM-IV diagnosis, highlighting the importance of using both approaches in children with NF1 (15). Molosh et al (16) also indicated a higher incidence of ASD in NF1 patients. Recently, results of meta-analysis of social function and ASD in children and adults with NF1 have been published. Findings from this analysis provide evidence that children and adults with NF1 exhibit significantly higher prevalence and severity of social dysfunction and ASD symptomatology. The results also support the presence of age, sex and comorbid ADHD as moderating factors for social outcomes in NF1 (17).

It is known that statins have a positive effect on the social and cognitive phenotype in animal knockout models. Recently a randomised controlled trial of simvastatin treatment for autism in young children with NF 1 (SANTA) was completed (18). This trial opens a novel area by studying statin effects in younger children with NF1 and co-morbid autism showing feasibility of peripheral MAPK assay and autism symptom measurement. Multiparametric imaging conducted in the study suggests possible simvastatin effects in brain areas previously associated with NF1 pathophysiology and the social brain network.

\section{Psychiatric diseases and neurofibromatosis type 1}

There is some question as to whether psychiatric and developmental disorders are over-represented in patients with NF1 particularly when patients with NF are compared to those with other chronic neurological disorders (19). Regarding this issue, Samuelsson et al conducted extensive, interesting and valuable research assessing general somatic, psychiatric, social and genetic as- 
pects of NF 1 in a carefully defined population of residents of Gothenburg in Sweden (20-22). Thirty-two of the 71 patients with NF1 (45\%) showed slight mental retardation and two of these were somewhat more retarded. This slight mental retardation was usually recognized during the early school years and it did not appear to be progressive. While patients affected with this problem were placed in remedial or special classes in school, they generally did not require any additional vocational training. There is reason to suspect that NF 1 itself leads to some impairment of intellectual development in all patients, for the intellectual achievements of those whose intelligence was judged to be within the normal range appeared to fall short of the average. None of the patients with normal intelligence had passed any academic examination and many showed achievements less than expected based on the achievements of their healthy relatives. In certain families, the NF appeared to be associated with mild mental retardation more than in other families. Mental retardation of a more severe degree, corresponding to special school level or lower, is not typical of NF 1 (21). Mental illness affected 23 $(33 \%)$ of the 69 patients with NF 1 who were included in the study with moderately severe or severe form being found in 15 of the 69 patients (22\%). The 23 mentally ill patients did not show any uniform clinical psychiatric syndrome. The most commonly occurring psychiatric diagnoses were depressive syndrome, anxiety state with vegetative dysfunction and organic brain syndrome. There was a significant positive relation between depressive syndrome and organic brain syndrome. Among patients with NF-1 there was a significantly positive relation between mental illness and mental retardation, but no significant positive relation between mental illness and physical severity of NF-1. Patients with mental illness also showed a significantly increased frequency of positive neurological findings indicating central nervous manifestations of NF-1 (22). In addition, the data from this study also indicated an excess of occupational disability, unemployment, or employment in a position characterised as not requiring special skills. Only four of 69 patients studied were gainfully employed in positions requiring three to four years of vocational training (21).

Recently, great attention is given to the association of posttraumatic stress disorder (PTSD) and various diseases particularly those with chronic duration. Huguen et al investigated the occurrence of PTSD in patients with NF (23). In this investigation a high level of PTSD was found following sporadic NF1 disclosure, especially in the parents of children with NF1. Better communication would be possible in order to minimize the post-traumatic stress symptoms in patients and their families if physicians were fully aware of the characteristics of this disease, its evolution and prognosis.

Electroconvulsive therapy (ECT) is the oldest form of therapy available for the treatment of severe major depression. It is highly effective in individuals with treatment resistance and when a rapid response is required. Thukral-Mahajan et al. reported the possibility of successful use of ECT in patients with NF and their results confirm the safety of ECT even in high-risk patients (24).

Psychotic disorders are another form of mental illness that may occur simultaneously with NFs, however it is still not clear whether it is coincidental or that a real causal connection between these two disorders exists (25).

\section{Cognitive difficulties and neurofibromatosis type 1}

There is increasing research related to cognitive and emotional difficulties as well as behavioural problems in individuals with NF. Various components of cognitive impairment were explored in order to give a better insight into their origin and development. The effect of dopamine in these disorders has also been explored. Further there are attempts to include social networks in aiding patients and their parents to better understand the difficulties and reduce their isolation (26-28). Results of the study concerning emotional and behavioural problems in children and adolescents with NF 1 (26) showed that attentional problems were associated with lower verbal $I Q$, male gender, younger age and ADHD-symptoms. A systematic review of literature regarding behaviour of children and adolescents with NF1 show significant alterations in language, reading, visuospatial skills, motor function, executive function, attention, behaviour, emotion and social skills.

Burgio et al (27) conducted a study aimed to identify the mathematical domains affected in adults with NF1 and the impact of the numerical 
difficulties for patients' daily activities. In this investigation they assessed 28 adult patients with NF1 and 28 healthy control participants. Obtained findings indicate that NF1 affects calculation but not the basic comprehension or representation of numbers in adult patients. These data have important implications for designing cognitive interventions customised to the cognitive profile of individuals with NF1. It was also shown that the presence of hyperintensity in magnetic brain resonance (NMR) findings is associated with poor cognitive performance. Analysis of these lesions could help predict cognitive changes in children with NF1 (28). Although NF1 can cause a wide range of cognitive deficits its foundation is still unknown and requires further investigation.

\section{Cognitive difficulties and NMR changes in neurofibromatosis type 1}

Different NMR studies have focused on neuroanatomical correlations between the NF1 cognitive phenotype, including grey and white matter volume changes $(29,30)$, white matter microstructure and functional connectivity changes $(31,33)$. NMR findings show that brain abnormalities in NF1 include increased white matter volume, increased subcortical grey matter volume (e.g., thalamus, right caudate), decreased cortical grey matter density, T2 hyperintensities (T2H), macrocephaly and reduced integrity of white matter microstructure (31,33-36). Thalamic T2H and volume abnormalities in the corpus callosum, putamen and amygdala were associated with cognitive deficits in NF1 $(3,33,35)$. There is also a debatable association of these deficits with local areas of T2-hyperintensities on NMR images, namely unidentified bright objects (UBOs). The study which included 36 children showed that the presence of UBOs in the thalamus and striatum may represent a neuroradiological pattern that influences performances in calculation and behaviour respectively in children with NF 1 (37).

Yoncheva et al published the results of a pilot study investigating the effect of the exercise of a computerized work memory program on functional NMR (fNMR) measures in children with NF1 and working memory deficits. Computerized at-home working memory training intervention was provided for 6-10 weeks. Investigators obtained pre- and post-treatment resting-state fNMR and cognitive measures. Two local resting state measures showed regionally specific changes after treatment and behavioural improvement on untrained tasks was also observed (38).

\section{Psychosocial skills and neurofibromatosis type 1}

Cipolletta et al.. conducted a study in which two hundred and forty participants were recruited, comprising 60 children and adolescents with NF1, 60 parents of children with NF1, 60 children and adolescents without NF1 and 60 parents of children without NF1. They showed that the psychological functioning, behaviour, self-image and quality of life (QOL) of children and adolescents with NF1 are compromised. Individuals with NF1 reported anxiety problems, poorer QOL and greater distortions in terms of self-image. When compared to the parents of healthy participants, the parents of NF1 participants reported having more concerns regarding the QOL, sociality, school performance and attention span of their children. Accordingly, health services should take into account the psychosocial difficulties associated with NF1 and design rehabilitation programs aimed at increasing NF1 children's interpersonal skills, improving their social life and QOL as well as promoting more adaptive behaviours. In addition, health care interventions should also involve the parents of children with NF1 (39).

Recent studies have documented an increased risk for social problems and features of ASD in children with Noonan syndrome (NS), NF1 and related disorders. In a study investigating the social skills of children with NF1 and NS, participants were given well-validated caregiver questionnaires assessing their child's social skills, language abilities, ADHD symptoms and anxiety. Results regarding overall social skills, average ratings of children in both clinical groups were similar indicating weaker social skills. Ratings of social skills were outside of normal limits for more than four of the ten children within the clinical groups, most of the deficits being mild or moderate. Fifteen percent of the children with NS and $5 \%$ of the children with NF1 were rated as having severe social skills impairment. Independent of diagnosis, having fewer ADHD symptoms or better social-pragmatic language skills was predictive of stronger social skills (40). Visual attention 
to faces within social scenes in children with NF1 and typically developing peers was also examined. Children with NF1 spend less time attending to faces than typically developing children when presented in social scenes. This findings contribute to a growing body of evidence suggesting that abnormal face processing is a key aspect of the social-cognitive phenotype of NF1 and appears to be related to autism spectrum disorder traits. Children with NF1 demonstrated atypical gaze behaviour when attending to faces and this gaze behaviour was characterized by normal initial fixation on faces but shorter face dwell time. Decreased attention to faces was associated with elevated autism traits in the sample with NF1 (41).

\section{Social problems and quality of life of patients with neurofibromatosis type 1}

More recently the possibilities of innovative applications of social media dedicated to those who care for children with chronic conditions can provide peer-to-peer support, shared experience, and reliable medical information was explored. The availability of this innovative approach can break their isolation, enable connection with other families and provide accurate information, advice and support from others facing similar challenges. The opportunity to communicate with others regarding the challenges they are faced with is very valuable and the shared experiences provide them with a sense of normalcy (42). Compared to unaffected children and adolescents of the general population, paediatric patients with NF1 have an increased risk of having social difficulties, mental health disorders, behavioural and emotional problems as well as diminished QOL. (43).

\section{Possibilities of medication treatment of behavioural impairment in patients with neurofibromatosis type 1}

Dopamine dysregulation has been identified as a key modulator of behavioural impairment in NF1 and a potential therapeutic target. Preclinical research demonstrates that reduced dopamine in the brains of genetically engineered NF1 mouse strains is associated with reduced spatial-learning and attentional dysfunction. Methylphenidate, a stimulant medication that increases dopaminergic and noradrenergic neurotransmission, have effect on the behavioural and dopamine abnormalities.
Although preliminary clinical trials have demonstrated that methylphenidate is effective in treating ADHD symptoms in children with NF1, its therapeutic effect on cognitive performance is unclear. Currently an ongoing randomised, doubleblind, placebo-controlled trial to assess the efficacy of methylphenidate for reducing attention deficits, spatial working memory impairments and ADHD symptoms in children with NF1 is being conducted (44). The results of this trial will be published in the near future.

\section{CONCLUSION}

The presence of a high incidence of autistic disorder, hyperkinetic disorder and cognitive problems in individuals with NFs is well known. Previous studies indicate the need for a multidisciplinary approach to the diagnosis and treatment of people with NFs. The results of research regarding the brain changes and the possibilities of pharmacological therapy will improve the understanding of mechanisms of comorbidity development, facilitate treatment outcome and enable the patients to better integrate into society as well as improve their overall QOL.

\section{REFERENCES}

1. Evans DG, Howard E, Giblin C, Clancy T, Spencer H, Huson SM, Lalloo F. Birth incidence and prevalence of tumor-prone syndromes: estimates from a UK family genetic register service. Am J Med Genet A. 2010; 152A (2):327-32. doi: 10.1002/ajmg.a.33139.

2. Huson SM. Recent developments in the diagnosis and management of neurofibromatosis. Arch Dis Child. 1989;64(5):745-749.

3. Hyman SL, Shores EA, North KN. The nature and frequency of cognitive deficits in children with neurofibromatosis type 1.Neurology. 2005;65:1037-44.

4. Hyman SL, Shores EA, North KN. Learning disabilities in children with neurofibromatosis type 1: subtypes, cognitive profile and attention-deficit-hyperactivity disorder. Med child Neurol. 2006;48:973-7.

5. Lehtonen A, Howie E, Trump D, et al. Behaviour in children with neurofibromatosis type 1: cognition, executive function, attention, emotion, and social competence. Dev Med Child Neurol. 2013;55:111-25.

6. Payne JM, Barton B, Shores EA, et al. Paired associate learning in children with neurofibromatosis type 1 : implications for clinical trials. J Neurol. 2013;260: 214-20. 
7. Juretić Z, Škevin V. Hiperaktivni poremećaj (ADHD). In: Nikolić S, Marangunić M, et al. Dječja i adolescentna psihijatrija. Zagreb: Školska.knjiga; 2004. p 111.

8. Basu TN, Gutmann DH, Fletcher JA, et al. Aberrant regulation of ras proteins in malignant tumour cells from type 1 neurofibromatosis patients. Nature. 1992; 356:713-5.

9. Sanchez-Marco SB, Lopez-Pison J, Serrano-Vinuales I, Troyas-Fernandez de Garayalde L, Lafuente-Hidalgo M, Monge-Galindo L. Neurofibromatosis type 1 and attention-deficit disorder. Our current experience. Rev Neurol. 2019;68(1):7-10.

10. Lidzba K, Grandstrom S, Lindenau J, Mautner VF. The adverse influence of attention-deficit disorder with or without hyperactivity on cognition in neurofibromatosis type 1. Dev Med Child Neurol 2012;54:892-897.

11. Koth CW, Cutting LE, Denckla MB. The association of neurofibromatosis type 1 and attention deficite hyperactivity disorder. Child Neuropsychol 2000;6:185-194.

12. Cohen R, Halevy A, Aharon S, Shuper A. Attention deficit hyperactivity disorder in neurofibromatosis type 1: Evaluation with a continuous performance test. J Clin Neurol. 2018;14(2):153-157. doi: 10.3988/ jcn.2018.14.2.153.

13. Lion-François L, Herbillon V, Peyric E, Mercier C, Gérard D, Ginhoux T, Coutinho V, Kemlin I, Kassai B, Desportes V, Michael GA. Attention and executive disorders in neurofibromatosis 1: Comparison between NF1 with ADHD symptomatology (NF1 + ADHD) and ADHD per se. J Atten Disord. 2017:10870547177 07579. doi: 10.1177/1087054717707579.

14. Bujas Petković Z. I. Dio: Dijagnoza i procjena. In: Bujas Petković Z, Frey Škrinjar J et al. Poremećaji autističnog spektra. Zagreb: Školska knjiga; 2010. p. 6-81.

15. Eijk S, Mous SE, Dieleman GC, Dierckx B, Rietman AB, de Nijs PFA, Ten Hoopen LW, van Minkelen R, Elgersma Y, Catsman-Berrevoets CE, Oostenbrink R, Legerstee JS. Autism spectrum disorder in an unselected cohort of children with neurofibromatosis type 1 (NF1). J Autism Dev Disord. 2018;48(7):2278-2285. doi: 10.1007/s10803-018-3478-0.

16. Molosh AI, Shekhar A. Neurofibromatosis type 1 as a model system to study molecular mechanisms of autism spectrum disorder symptoms. Prog Brain Res. 2018;241:37-62. doi: 10.1016/bs.pbr.2018.09.014.

17. Chisholm AK, Anderson VA, Pride NA, Malarbi S, North KN, Payne JM. Social function and autism spectrum disorder in children and adults with neurofibromatosis type 1: a systematic review and meta-analysis. Neuropsychol Rev. 2018;28(3):317-340. doi: 10.1007/ s11065-018-9380-x.

18. Stivaros S, Garg S, Tziraki M, Cai Y, Thomas O, Mellor J, Morris AA, Jim C, Szumanska-Ryt K, Parkes LM, Haroon HA, Montaldi D, Webb N, Keane J, Castellanos FX, Silva AJ, Huson S, Williams S, Gareth Evans D, Emsley R, Green J; SANTA Consortium i coll. Randomised controlled trial of simvastatin treatment for autism in young children with neurofibromatosis type 1 (SANTA). Mol Autism. 2018;9:12. doi: 10.1186/ s13229-018-0190-z.

19. DeFries JC, Vandenberg SG, McClearn GE. Genetics of specific cognitive abilities. Annu Rev Genet. 1976;10: 179-207.

20. Samuelsson B, Samuelsson S. Neurofibromatosis in Gothenburg, Sweden. I. Background, study design and epidemiology. Neurofibromatosis. 1989;2:6-22.

21. Samuelsson B, Riccardi VM. Neurofibromatosis in Gothenburg, Sweden. III. Psychiatrics and social aspects. Neurofibromatosis. 1989;2:84-106.

22. Samuelsson B, Riccardi VM. Neurofibromatosis in Gothenburg, Sweden. II. Intellectual compromise. Neurofibromatosis. 1989;2:78-83.

23. Huguen J, Audebert-Bellanger S, Brenaut E, Misery L, Abasq-Thomas C. Post-traumatic stress disorder in patients and relatives following a diagnosis of de novo neurofibromatosis type 1. Acta Derm Venereol. 2018; 98(2):291-293. doi: 10.2340/00015555-2813.

24. Thukral-Mahajan P, Shah N, Kalra G, Andrade C4. Electroconvulsive therapy for medication-refractory depression in a patient with ruptured intracranial dermoid cyst, meningioma, and neurofibromatosis. Indian J Psychiatry. 2017;59(4):493-495. doi: 10.4103/psychiatry.

25. Mirza T, Majeed MH. Neurofibromatosis and psychosis: coincidence or co-occurrence? Aust N Z J Psychiatry. 2018; doi: 10.1177/0004867418818360.

26. Rietman $\mathrm{AB}$, van der Vaart $\mathrm{T}$, Plasschaert $\mathrm{E}$, Nicholson BA, Oostenbrink R, Krab LC, Descheemaeker MJ, Wit MY, Moll HA, Legius E, Nijs PFA. Emotional and behavioral problems in children and adolescents with neurofibromatosis type 1 . Am J Med Genet B Neuropsychiatr Genet. 2018;177(3):319-328. doi: 10.1002/ ajmg.b.32612.

27. Burgio F, Benavides-Varela S, Arcara G, Trevisson E, Frizziero D, Clementi M, Semenza C. Numerical activities of daily living in adults with neurofibromatosis type 1. J Intellect Disabil Res. 2017;61(11):1069-1077. doi: 10.1111/jir.12408.

28. Torres Nupan MM, Velez Van Meerbeke A, López Cabra CA, Herrera Gomez PM. Cognitive and behavioral disorders in children with neurofibromatosis type 1 . Front Pediatr. 2017;5:227. doi: 10.3389/fped.2017.00227.

29. Schütze M, de Souza Costa D, de Paula JJ, Malloy-Diniz LF, Malamut C, Mamede M, Miranda DM, Brammer M, Romano-Silva MA. Use of machine learning to predict cognitive performance based on brain metabolism in neurofibromatosis type 1. PLoS One. 2018; 13(9):e0203520. doi: 10.1371/journal.pone.0203520.

30. Duarte JV, Ribeiro MJ, Violante IR, Cunha G, Silva E, Castelo-Branco M. Multivariate pattern analysis reveals subtle brain anomalies relevant to the cognitive phenotype in neurofibromatosis type 1 . Hum Brain Mapp. 2014;35:89-106. 
31. Koini M, Rombouts S a. RB, Veer IM, Van Buchem MA, Huijbregts SCJ. White matter microstructure of patients with neurofibromatosis type 1 and its relation to inhibitory control. Brain imaging Behav.2016;https:// doi.org/10.1007/s11682-016-9641-3.

32. Loitfelder M, Huijbregts SCJ, Veer IM, Swaab HS, Van Buchem MA, Schmidt R, et al. Functional connectivity changes and executive and social problems in neurofibromatosis type 1. Brain Connect. 2015;5:312-320. http://doi.org/10.1089/brain.2014.0334.

33. Huijbregts SC, Loitfelder M, Rombouts SA, Swaab H, Verbist BM, Arkink EB, et al. Cerebral volumentric abnormalities in neurofibromatosis type 1: associations with parent ratings of social and attention problems, executive dysfunction, and autistic mannerisms. J Neurodev Disord. 2015;7:32.https://doi.org/10.1186/ s11689-015-9128-3.

34. Karlsgodt KH, Rosser T, Lutkenhoff ES, Cannon TD, Silva A, Bearden CE. Alterations in white matter microstructure in neurofibromatosis-1. PloS ONE. 2012;7: e47854.http://doi.org/10.1371/journal.pone.0047854.

35. Payne JM, Moharir MD, Webster R, North KN. Brain structure and function in neurofibromatosis type 1 : current concepts and future directions. Neurol Neurosurg Psychiatry. 2010;81:304-309. https://doi.org/ 10.1136/jnnp.2009.179630.

36. Violante IR, Ribeiro MJ, Silva ED, Castelo-Branco M. Gyrification, cortical and subcortical morphometry in neurofibromatosis type 1: an uneven profile of developmental abnormalities. J Neurodev Disord. 2013;5:3. https://doi.org/10.1186/1866-1955-5-3.

37. Parmeggiani A, Boiani F, Capponi S, Duca M, Angotti M, Pignataro V, Sacrato L, Spinardi L, Vara G, Maltoni L, Cecconi I, Pastore Trossello M, Franzoni E. Neuropsychological profile in Italian children with neurofibromatosis type 1 (NF1) and their relationships with neuroradiological data: Preliminary results. Eur J Paediatr Neurol. 2018; 22(5):822-830. doi: 10.1016/j.ejpn. 2018.04.016.

38. Yoncheva YN, Hardy KK, Lurie DJ, Somandepalli K, Yang L, Vezina G, Kadom N, Packer RJ, Milham MP, Castellanos FX, Acosta MT. Computerized cognitive training for children with neurofibromatosis type 1: A pilot resting-state fMRI study. Psychiatry Res Neuroimaging. 2017;266:53-58. doi: 10.1016/j.pscychresns. 2017.06.003.

39. Cipolletta S, Spina G, Spoto A. Psychosocial functioning, self-image, and quality of life in children and adolescents with neurofibromatosis type 1 . Child Care Health Dev. 2018; 44(2):260-268. doi: 10.1111/cch.12496.

40. Pierpont EI, Hudock RL, Foy AM, Semrud-Clikeman M, Pierpont ME, Berry SA, Shanley R, Rubin N, Sommer K, Moertel CL. Social skills in children with RASopathies: a comparison of Noonan syndrome and neurofibromatosis type 1. J Neurodev Disord. 2018; 10(1):21. doi: 10.1186/s11689-018-9239-8.

41. Lewis AK, Porter MA, Williams TA, Bzishvili S, North KN, Payne JM. Attention to faces in social context in children with neurofibromatosis type 1 . Dev Med Child Neurol. 2018. doi: 10.1111/dmcn.13928.

42. Akre C, Polvinen J, Ullrich NJ, Rich M. Children's at Home: Pilot study assessing dedicated social media for parents of adolescents with neurofibromatosis type 1. J Genet Couns. 2018;27(2):505-517. doi: 10.1007/ s10897-018-0213-0.

43. Domon-Archambault V, Gagnon L, Benoît A, Perreault $S$. Psychosocial features of neurofibromatosis type 1 in children and adolescents. J Child Neurol. 2018;33(3):225-232. doi: 10.1177/0883073817749367.

44. Pride NA, Barton B, Hutchins P, Coghill DR, Korgaonkar MS, Hearps SJC, Rouel M, Malarbi S, North KN, Payne JM. Effects of methylphenidate on cognition and behaviour in children with neurofibromatosis type 1: a study protocol for a randomised placebocontrolled crossover trial. BMJ Open. 2018; 8(8): e021800. doi: 10.1136/bmjopen-2018-021800.

Corresponding author: Marija Bogadi, Psychiatric Hospital for Children and Adolescents, Ulica Ivana Kukuljevića 11, 10000 Zagreb, Croatia.e-mail: marija.bogadi@gmail.com 